\title{
Socio-ecological adaptation to Early-Holocene sea-level rise in the western Mediterranean
}

\author{
Elodie Brisset ${ }^{\mathrm{a}, \mathrm{b}, *}$, Francesc Burjachs ${ }^{\mathrm{a}, \mathrm{b}, \mathrm{c}}$, Bruno José Ballesteros Navarro ${ }^{\mathrm{d}}$, \\ Javier Fernández-López de Pablo ${ }^{\mathrm{a}, \mathrm{b}}$ \\ a IPHES, Institut Català de Paleoecologia Humana i Evolució Social, Tarragona, Spain \\ b Àrea de Prehistòria, Universitat Rovira $i$ Virgili, Tarragona, Spain \\ ${ }^{\mathrm{c}}$ ICREA, Catalan Institution for Research and Advanced Studies, Barcelona, Spain \\ d Instituto Geológico y Minero e España, Valencia, Spain
}

\section{A R T I C L E I N F O}

Keywords:

Coastal barrier-lagoon

Palaeoenvironments

Coastal Archaeology

Mesolithic

Neolithic

\begin{abstract}
A B S T R A C T
Consecutively to the global sea-level rise, coastal landscapes significantly changed during the Early Holocene. We explored how coastal mutations have affected ancient human systems in the western Mediterranean. The Pego-Oliva basin (Spain) provides a thick sediment sequence located in proximity to two well-studied Mesolithic and Neolithic archaeological sites. Based on 16 sediment cores, sedimentological analyses, ${ }^{14} \mathrm{C}$ dates, and integration of previous works, we reconstructed the architecture of the sedimentary facies and the chronology of deposition for the last 9500 years. From 9500 to 8200 cal. BP, the stepwise inland migration of the coastline is characterised by the deposition of peat layers at distinct depths indicating four phases of barrier-lagoon systems development. The marine transgression caused the disappearance of the lagoon at $8200 \mathrm{cal}$. BP, and reached a maximum inland position at $7300 \mathrm{cal}$. BP. Since $5800 \mathrm{cal}$. BP, sea-level stabilisation induced coastal progradation and barrier-lagoon system construction. Five marine flooding phases dated at 9500, 9100-9000, 8750-8650, 8450-8200, and 8100-7300 cal. BP match Atlantic meltwater pulses. Comparison to archaeology shows that the long-lasting Mesolithic occupation corresponds to the presence of coastal offering easily exploitable local intertidal resources. In contrast, during the Late Mesolithic, we observe a lagoon contraction and the reduction of lagoon bivalves size arguing for a decrease in resource productivity. This changes in the lagoon ecosystems negatively impacted to Late Mesolithic populations leading to a less intense occupation of this area. Therefore, the 700 years' temporal hiatus between the last hunter-gatherers and the first farmers occupying this area is explained by the disappearance of the formerly exploited biotopes because of sea-level rise, a situation that may have been aggravated by coincidence of the $8200 \mathrm{cal}$. BP climate event. The maximal sea transgression corresponded to a shift from intertidal to infralittoral species between the Impressa/Precardial and the Postcardial Neolithic, indicating a good adaptation to changing environments at that time. However, comparison between Late Mesolithic to Early Neolithic suggests that communities with different cultural baggage have had a different perception of the same environment. By the past perspective, it emphasises that perception of the ecosystem value as a benefit or constraint, and of the risks associated with sea-level rise, relies first on the local and regional scales adaptive capacity of society to global changes.
\end{abstract}

\section{Introduction}

Coupled paleoenvironmental and archaeological studies offer longterm perspectives of the resilience of societies to current global changes (Van de Noort, 2011). However, understanding how past humans interrelate to the environment further temporal comparisons between climatic, environmental and archaeological archives need to be implemented, by accessing the cascading set of socio-ecosystem responses from the global to the local scale. Following the end of the Last Glaciation, the coastal configuration profoundly changed resulting in the global sea-level rise flooding of the Late Pleistocene littoral plains (Shennan et al., 2000; Jakobsson et al., 2017). Sea-level rise was translated into the loss of human settlement areas, reduction of hunting territories, and modification of coastal ecosystems. Opposite views on whether coastal plains have been effectively attractive for prehistoric communities persist (Bailey, 2004). While some authors have proposed

\footnotetext{
* Corresponding author at: IPHES, Institut Català de Paleoecologia Humana i Evolució Social, Tarragona, Spain.

E-mail address: elodie.brisset@gmail.com (E. Brisset).
} 
that Holocene coasts consisted of marginal areas, compared to the hinterland, others have argued for coastal landscapes as an interface between land and sea being places of countless opportunities for early humans (Dupont et al., 2009; Walsh, 2014; Benjamin et al., 2017). In the Mediterranean, marine resources have represented a low but significant part of the human dietary needs during the Early Holocene (Costa et al., 2003; Goude et al., 2017). However, the interaction between humans and their environments were not restricted to consumption purposes. Geomorphological heterogeneity and the associated biotic richness and diversity (Burnett et al., 1998) may have rendered these areas favourable for a large range of activities including shell gathering, fishing, hunting, agriculture and they well as offered easily accessible corridors for human movements (Erlandson, 2001). The issue is to determine to what extent Early to Mid-Holocene changes on coastal biotopes associated to sea-level rise have affected patterns of human exploitation and occupation (Colonese et al., 2011; Mannino et al., 2011; Colonese et al., 2018).

This work focuses on the paleogeographic reconstruction of coastal and human systems in the course of the Mesolithic and the Neolithic in the Pego-Oliva basin (Valencia, Spain). In the Western Mediterranean, recent studies have investigated human-environmental interactions during the prehistoric period (e.g. Dolez et al., 2015; Currás et al., 2017; Fontana et al., 2017; Vacchi et al., 2017; Melis et al., 2018). However, the low preservation of Early Holocene coastal sites as well as the paucity of integrated research programs correlating archaeological and palaeoenvironmental records, have prevented the answering of this question. Pego-Oliva area is a very well-adapted case study site for investigating the relationship between environmental changes and prehistoric socio-economic dynamics. This area provides sedimentary records to identify the coastal evolution from the Middle Pleistocene to the Holocene (Torres et al., 2014). Previous studies based on sedimentary and paleontological analyses have established the main trend of the morphogenetic evolution (Dupré et al., 1988; Viñals et al., 1989; Fumanal et al., 1993a, 1993b; Viñals, 1995; Viñals and Fumanal, 1995; Ballesteros Navarro et al., 2009), but are insufficient to be compared and contrasted to the human record given the low chronological resolution. In addition, the interest of this area lies in its proximity to two major archaeological sites. A renewed record has been produced, that includes dated Mesolithic human remains (Gibaja et al., 2015) and shell midden deposits (Fernández-López de Pablo, 2016), isotopic and zooarchaeological reconstructions of dietary patterns (García Guixé et al., 2006; Fernández-López de Pablo and Gabriel, 2016) and the discovery of Early Neolithic occupations containing rich mollusc assemblages (Esquembre-Bebia et al., 2008; Bernabeu and Martí, 2014), representing the introduction of farming dispersal episodes by seafaring pioneering groups. In this study, we first reconstruct the coastal morphogenetic evolution during the Early and Middle Holocene; then we compare the sedimentary evolution at Pego-Oliva with other Mediterranean sedimentary records to evaluate the driving forces (e.g. climate change) behind the Early Holocene relative sea-level changes, and finally, we explore how coastal mutation affected prehistoric settlement and subsistence patterns.

\section{Study site}

The study area is located in the south of the Valencian gulf in Western Mediterranean (Fig. 1A). This area is characterised by a succession of flat coastal plains occupied by lagoons (e.g. Albufera de Valencia) and marshes, interrupted to the south by sea cliffs (Viñals and Fumanal, 1995). The saltmarsh of Pego-Oliva is separated from sea by an $8 \mathrm{~km}$ long and $1.5 \mathrm{~km}$ wide sand barrier system parallel to the coastline. Several washover fans passing through the barrier are developed above the marsh. The saltmarsh is fed by two intermittent rivers fed by runoff, karstic springs and the ground-water nappe. The area is artificially drained for agricultural purposes and it is subjected to saline water intrusions resulting in groundwater exploitation
(Ballesteros Navarro et al., 2009). Colluvial glacis (Fig. 1B) developed in the mountain feet are attributed to the Pleistocene (Viñals and Fumanal, 1995). A lower level of colluvial fans is partly developed on the marsh. The catchment is oriented SW-NE, dominated by Upper Cretaceous limestone mountains reaching $700 \mathrm{~m}$ a.s.l. The basin floor consists of Miocene formations (Fig. 1B). A thick Pleistocene sediment sequence is deposited below the sea level (Torres et al., 2014). Beachrocks attributed to the Early Holocene have been identified between -25 and $30 \mathrm{~m}$ (Fig. 1B) according to the previous stratigraphic correlation based on sediment cores and underwater seismic profiles (Somoza and Rey, 1991; Fumanal et al., 1993b; Rey and Fumanal, 1996).

The study area has been successively occupied by Mesolithic and Neolithic human communities during the Early to Mid-Holocene. El Collado is an open-air site that has uncovered a Mesolithic cemetery composed of 14 burials associated with a stratigraphic sequence containing lithic, faunal and shellfish assemblages. Several studies have been published on the stratigraphic sequence (Fernández-López de Pablo, 2016), lithic typology (Aparicio, 2014), chronology of the funerary practices (Gibaja et al., 2015), human diet (García Guixé et al., 2006), and exploitation of littoral resources (Fernández-López de Pablo and Gabriel, 2016). The chronological model of El Collado (FernándezLópez de Pablo, 2016) integrates ${ }^{14} \mathrm{C}$ dates on human burials with dates from previous and posterior occupation horizons. This site includes two Early Mesolithic phases (level IV: 9830-9550 cal. BP and level II: 9435-8475 cal. BP) and one Late Mesolithic phase (level I: $8510-8390 \mathrm{cal}$. BP to $8500-8060 \mathrm{cal}$. BP). Despite an extensive program of dating, there is no evidence of Late Mesolithic occupation during and after the chronological span of the 8200 cal. BP event, suggesting the end of the human occupations at this time. El Barranquet is an open-air Early Neolithic site comprising two occupational phases (Esquembre-Bebia et al., 2008). The first phase, characterised by Impressa/Precardial pottery, has been dated at 7550-7320 cal. BP. Both the ceramic record and the chronology show strong cultural affinities with the impressa Neolithic facies documented in the Ligurian-Provencal arc, associated with the first spread of farming in the western Mediterranean (Bernabeu et al., 2009). The second phase (UE 74 and 71) corresponds to the Postcardial Neolithic which is dated in the region at 6800-6000 cal. BP by its decorative style. Preliminary works have provided paleodietary information from malacological assemblages (Luján Navas, 2016).

\section{Material and methods}

Six new boreholes were carried out in the Pego-Oliva basin in 2017 using a geotechnical piston corer comprising core segments of $50 \mathrm{~cm}$ and a $10 \mathrm{~cm}$ core catcher. The core segments were then stored in $60 \mathrm{~cm}$ width boxes in a cold room $\left(2{ }^{\circ} \mathrm{C}\right)$. The borehole locations were acquired by GPS and altitude is reported according to LIDAR data (altimetric accuracy of $0.3 \mathrm{~cm}$ ) of the Institut Cartogràphic Valencià with mean sea-level as a benchmark (P17-2: N38.87124, W0.04462, 0.89 m; P173: N38.86138, W0.05557, $0.67 \mathrm{~m}$; P17-4: N38.85476, W0.06613, $1.86 \mathrm{~m}$; P17-5: N38.85556, W0.07360, $3 \mathrm{~m}$; P17-7: N38.85790, W0.06142, 0.67 m; P17-8: N38.87569, W0.08774, $1.8 \mathrm{~m}$ ). The lithostratigraphy has been described based on colour, texture, grain-size, and presence of macro-remains (plant debris, shells, gravels).

Thirty-nine volumetric samples were obtained from the different sedimentary facies from three representing cores (P17-3, P17-5, and P17-7) and homogenised. A volume of $5 \mathrm{~cm}^{3}$ was dedicated to dry density and loss on ignition analyses. These samples were weighed, dried at $60^{\circ} \mathrm{C}$ for 7 days, and weighed again to estimate the dry density. These samples were then ignited at $550{ }^{\circ} \mathrm{C}$ for $5 \mathrm{~h}$ (Meyers and Teranes, 2001) and weighed to measure the Total Organic Carbon (TOC), and then ignited again at $950{ }^{\circ} \mathrm{C}$ for $1 \mathrm{~h}$ to estimate the Total Inorganic Carbon (TIC). The remaining ignited fraction corresponds to the NonCarbonate Inorganic Residue (NCIR). The remaining sample volume 


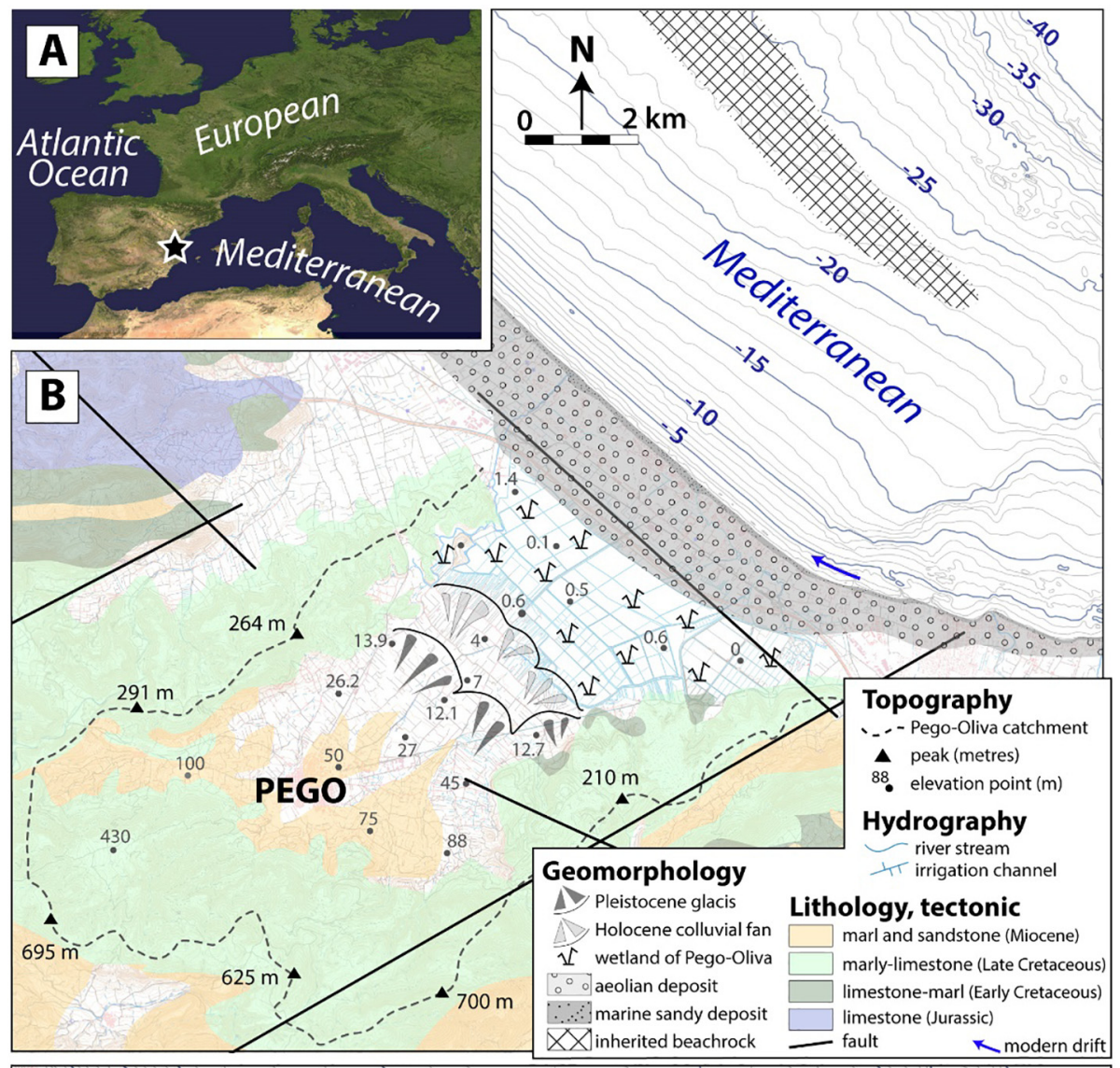

Fig. 1. A) Localisation of the study area (star) in the western Mediterranean. B) Geological and geomorphological contexts of the Pego-Oliva wetland. The topographical map is based on LIDAR data of the Institut Cartogràfic Valencià, and the bathymetric map from seismic data of the Cartografià Marine of the Instituto Franklin. C) Location of the boreholes carried out in the basin (green: this study, orange: Ballesteros Navarro et al., 2009; and blue: Dupré et al., 1988; Viñals et al., 1989; Fumanal et al., 1993a, 1993b) and, of the transects discussed in the manuscript. The seismic profile carried out by Viñals and Fumanal (1995) is approximately located on the a'-b' profile. (For interpretation of the references to colour in this figure legend, the reader is referred to the web version of this article.)

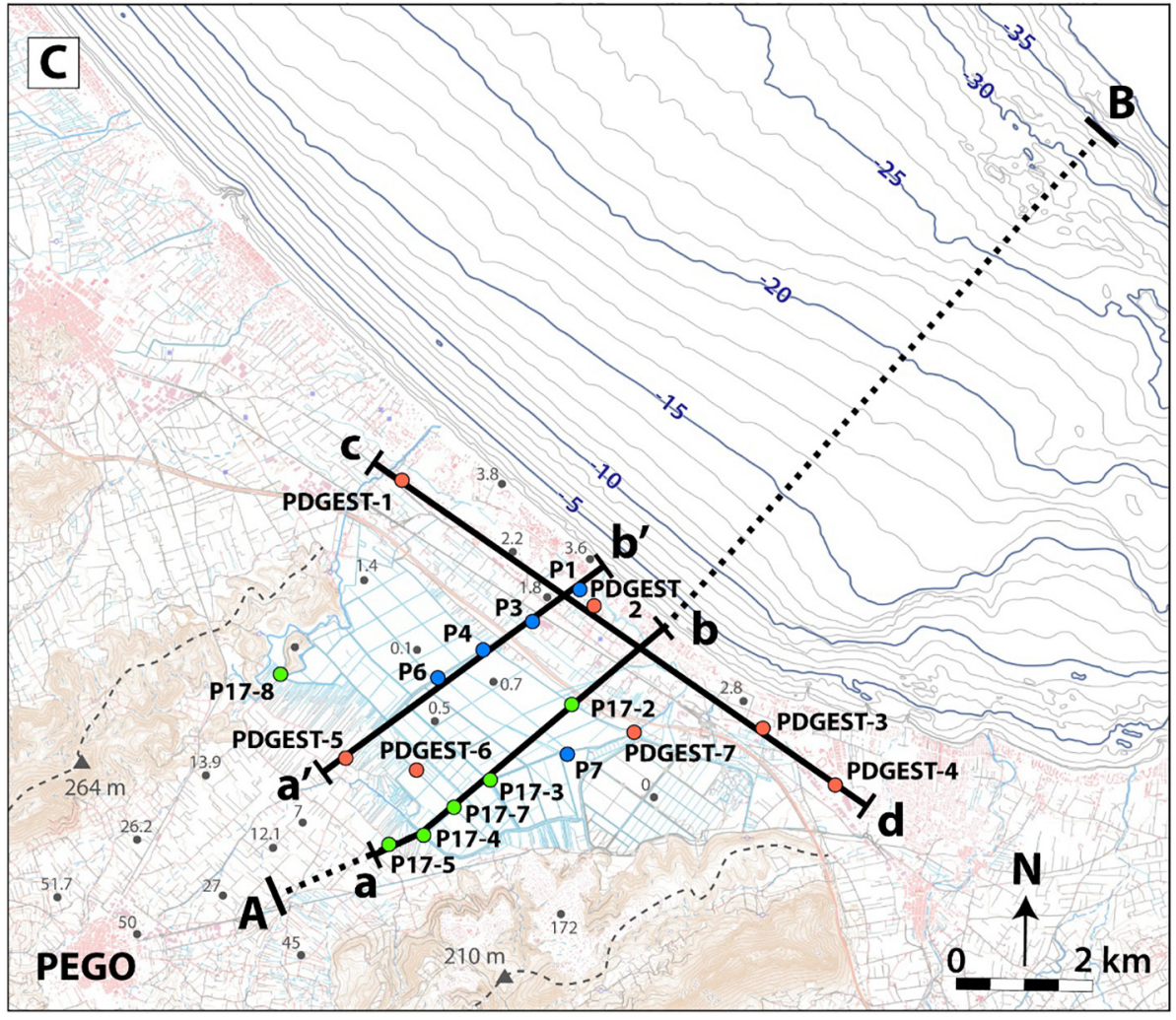

was dried and sieved at meshes of $2 \mathrm{~mm}, 150 \mu \mathrm{m}$, and $50 \mu \mathrm{m}$ for grainsize analysis. Mesh residues were weighed to estimate the percentage of gravel, sand, silt, and clays.

Terrestrial vegetal macro-remains (wood, charcoal, peat stem and leaves) were manually picked under a binocular microscope and ${ }^{14} \mathrm{C}$ dated (Radiocarbon Laboratory of Poznan). The ${ }^{14} \mathrm{C}$ ages were calibrated in calendar years Before Present (cal. BP) using the Clam R package (Blaauw, 2010) that includes the IntCal13 calibration curves 
(Reimer et al., 2013). Two models have been computed that takes into account the probability density function of the ${ }^{14} \mathrm{C}$ ages and a confidence interval of $2 \sigma$ (10,000 iterations). The age-depth model, corresponding to the vertical axis, is calculated using a smooth spline function (Supplementary material 1). The age-distance model, corresponding to the horizontal axis, is calculated using a linear function (Supplementary material 2).

Ten boreholes previously published have been integrated to this study (Dupré et al., 1988; Viñals et al., 1989; Fumanal et al., 1993b; Viñals and Fumanal, 1995; Ballesteros Navarro et al., 2009). Sedimentological descriptions have been harmonised on the basis of the analysis carried out for this study, and the consultation of the cores PDGEST-2 and PDGEST-7 at the IGME geological samples library (Penarroya, Spain). Three samples were taken in PDGEST-2 for ${ }^{14} \mathrm{C}$ dating. The radiocarbon ages have been re-calibrated using IntCal13 and Marine13. For the marine sample (Glycimeris shell, $6130 \pm 100$ years $\mathrm{BP})$, an isotopic fractionation $\left(\delta^{13} \mathrm{C}=1.14 \% 0\right)$ and an average marine reservoir effect $(\Delta R)$ of $94 \pm 61$ years have been accounted for in the study site based on the closest $\Delta \mathrm{R}$ estimates, i.e. Banyuls in France and Castiglione in Algeria (Siani et al., 2000; Reimer et al., 2002).

\section{Results}

\subsection{Geometry of the sedimentary bodies}

The sediment cores are characterised by six sedimentary units (Fig. 2). Unit 1, corresponds to the pre-Holocene infilling basin (Fumanal et al., 1993a; Torres et al., 2014). It consists of colluvial facies made of a red-brown clay matrix with heterometric coarse gravel that laterally corresponds to a palustrine facies made of light beige silt-clays dominated by calcium carbonates. In discontinuity to Unit 1 , the Holocene sedimentation starts in Unit 2 . Unit 2 consists of decimetre-thick homogeneous black peat facies (Fig. 2) rich in organic matter (TOC $=45 \%$ ) and Non-Carbonate Inorganic Residues (NCIRs $=43 \%$ ), having a relatively low density $\left(0.5 \mathrm{~g} / \mathrm{cm}^{3}\right)$. Benthic foraminifera are present (Ammonia beccarii) together with Cerastoderma glaucum bivalves that are characteristic of lagoonal environmental conditions influenced by marine waters (Dupré et al., 1988; Torres et al., 2014). Unit 3 is decametre-thick, dominated by a calcium carbonate sand fraction (mean sand value $=60 \%$, Total Inorganic Carbon $=13.5 \%$ in a greyblue clay matrix (29\%). TOC is minimal (2\%). From bottom to top, increasing proportions in benthic foraminifera (Haynesina germanica and Ammonia beccarii compared to Elphidium excavatum and Ammonia perlucida) suggest a decrease in salinity over this littoral facies, from open-sea to semi-enclosed lagoon environments (Dupré et al., 1988). Unit 4 consists of a decametre-thick homogeneous to fibrous black peat sediments (TOC $=55 \%$ ) that are developing up to the core surface of several boreholes. Microfossil assemblages are dominated by benthic foraminifera $A$. beccarii reflecting a lagoon environment, mostly influenced by brackish waters subjected to marine intrusion (Dupré et al., 1988). In one borehole, the sedimentary sequence is capped by Unit 5 , characterised by dense $\left(1.8 \mathrm{~g} / \mathrm{cm}^{3}\right)$ minerogenic clays $(\mathrm{NCIR}=88 \%$, clays $=92 \%$ ). Isolated angular gravels occurred in this unit (maximum of $7 \%$ ). This facies corresponds to a terrestrial detrital environment, characteristic of colluvial fan activity (Fig. 1B). This unit classification (Unit 1 to 5), based on sedimentological and biological content, is

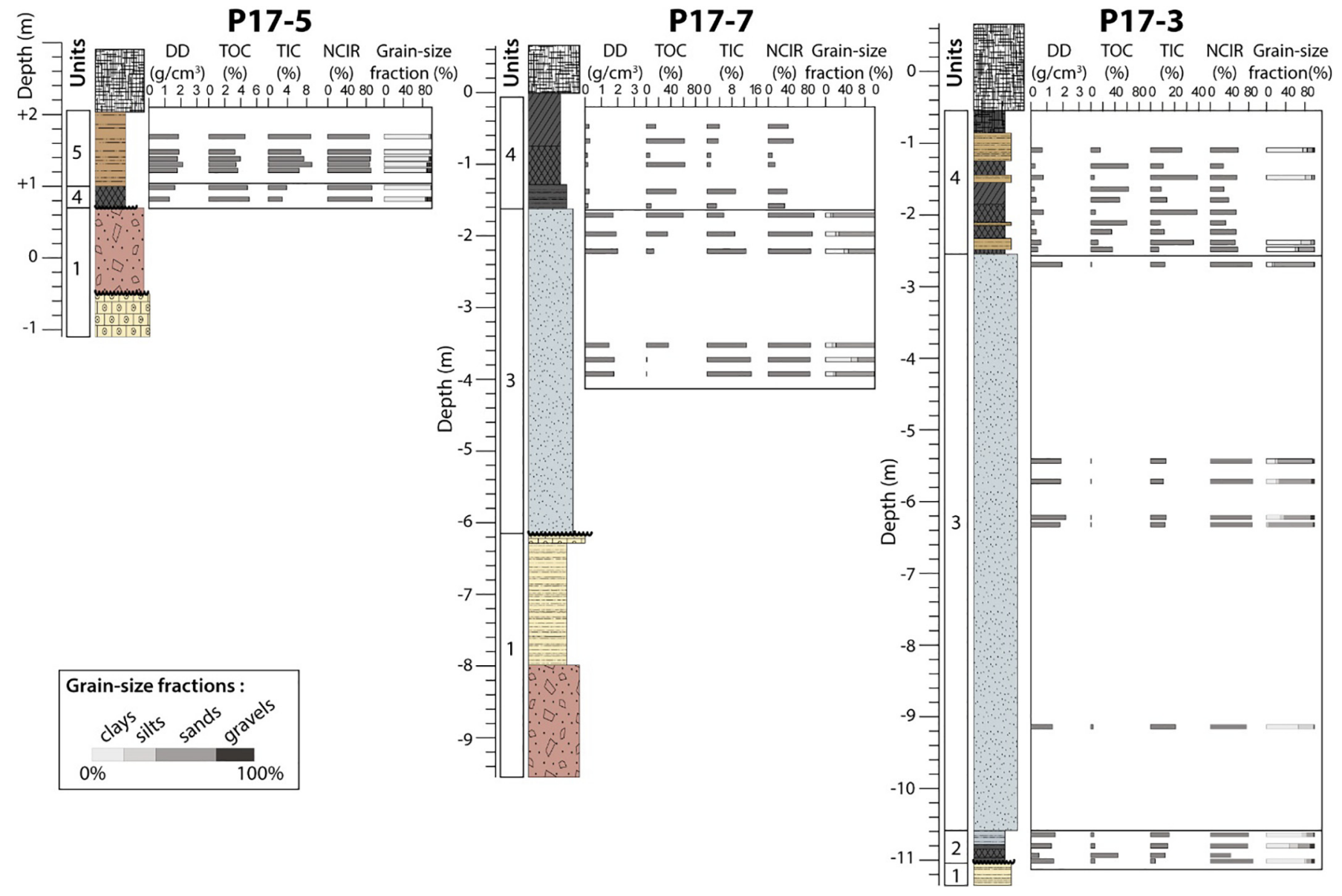

Fig. 2. Sedimentological analysis carried out on three selected representative boreholes. Results are represented by histogram bars plotted at the corresponding depth of the sample. Dry Density (DD), Total Organic Carbon (TOC), Total Inorganic Carbon (TIC) and Non-Carbonate Inorganic Residue (NCIR). Core depth is given below (negative value) or above (positive value) the current mean sea-level. 

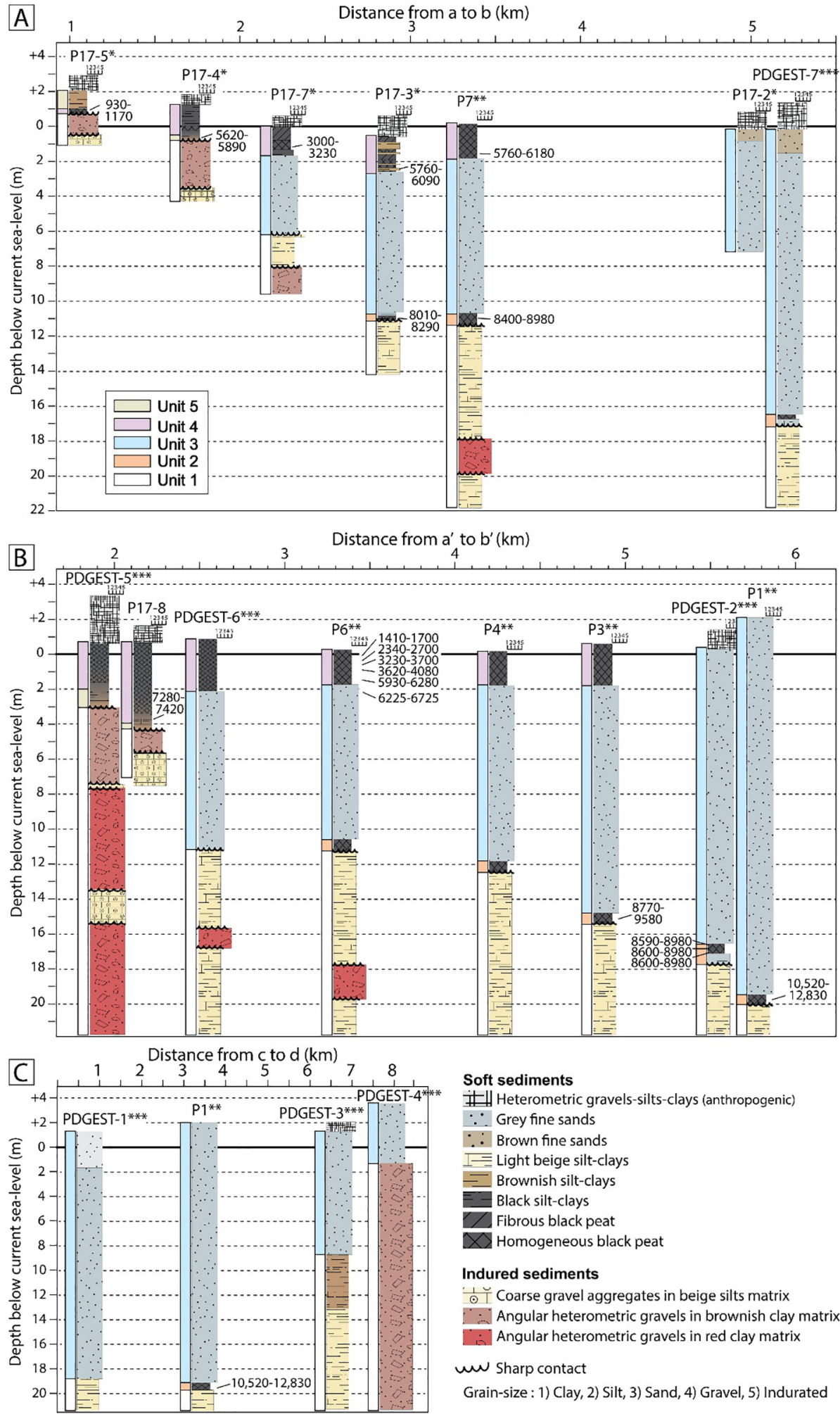

Soft sediments

I\# Heterometric gravels-silts-clays (anthropogenic)

$\because$ Grey fine sands

$\because$ Brown fine sands

E Light beige silt-clays

- Brownish silt-clays

Black silt-clays

Fibrous black peat

$X$ Homogeneous black peat

Indured sediments

$\frac{1}{\odot} \breve{Y}$ Coarse gravel aggregates in beige silts matrix

$\therefore$ Angular heterometric gravels in brownish clay matrix

$\therefore$ Angular heterometric gravels in red clay matrix

w Sharp contact

Grain-size : 1) Clay, 2) Silt, 3) Sand, 4) Gravel, 5) Indurated
Fig. 3. Lithostratigraphic description of the sediment cores of the Pego-Oliva wetland according to their respective position on the three transects referring to Fig. 1C: A) southern land to sea transversal profile ab; B) northern land to sea transversal profile a'-b'; C) longitudinal profile of the shoreline c-d. Thick black lines indicate the modern mean sea-level. Simplified chronostratigraphy based is shown beside sedimentary logs (colours refer to units 1 to 5). Radiocarbon ages are reported by the 2 sigma calibration interval. Asterisks indicate references to this study (*), Dupré et al., 1988; Viñals and Fumanal, 1995; Fumanal et al., 1993a, 1993b (**) and Ballesteros Navarro et al., $2009(* * *)$. applied to all the boreholes taken in the basin, including those from previous studies (Fig. 3).

Fig. 1C shows the position of the boreholes: two transects (Fig. 3A and $\mathrm{B}$ ) across the basin perpendicularly to the shoreline, and a parallel one (Fig. 3C) located on the beach barrier. All the boreholes except P17-2 reach the Pleistocene deposits of Unit 1 (Torres et al., 2014). The thickness of the Holocene infilling increases from the land toward the sea (1.5 $\mathrm{m}$ in P17-5 to $22 \mathrm{~m}$ in P1) and from the South-east of the basin toward the central part (5.5 m in PDGEST-4, $10 \mathrm{~m}$ in PDGEST-3 and $22 \mathrm{~m}$ in P1 and PDGEST-1). Unit 2 (lagoon facies) occurs in 8 boreholes at four depths (Fig. 3): $-20 \mathrm{~m}$ in P1-7, $-17.5 \mathrm{~m}$ in PDGEST-2 and PDGEST-7, $-15.5 \mathrm{~m}$ in P3, $-11 \mathrm{~m}$ in P4 and P17-3, P6 and P7. Unit 2 is deeper toward the sea and shallower landward, reflecting a backstepping retrogradational sequence associated with a transgressive system tract. Unit 2 is always capped by the shoreface sand facies (Unit 3) reflecting a marine transgression that reached its maximum of 
Table 1

Radiocarbon ages in their sedimentation context in relation with the sea-level position. Relative Sea-Level (RSL) inferred depth, vertical error, and type of index point (Vacchi et al., 2016). Numbering refers to 1) this study; 2) Dupré et al., 1988; 3) Viñals and Fumanal, 1995; 4) Fumanal et al., 1993a, 1993b. The ${ }^{14}$ C age of the sample R-2013 is reported corrected of its $\delta^{13} \mathrm{C}$ fractionation error of $1.14 \%$. The ages that have been excluded in the age-depth model are in italics.

\begin{tabular}{|c|c|c|c|c|c|c|c|c|c|c|c|c|c|}
\hline Core & Lat. & Lon. & $\begin{array}{l}\text { Depth } \\
\text { (m asl) }\end{array}$ & Material & Facies & Lab. code & ${ }^{14} \mathrm{C}$ years BP & $\Delta \mathrm{R}(\mathrm{yrs})$ & $\begin{array}{l}\text { Minimum } \\
\text { age cal. BP }\end{array}$ & $\begin{array}{l}\text { Maximum } \\
\text { age cal. BP }\end{array}$ & Ref & RSL (m) & $\begin{array}{l}\text { Type of } \\
\text { index } \\
\text { point }\end{array}$ \\
\hline$P 17-4$ & 38.854 & 0.066 & 0 & Charcoals, peat & Lagoonal & Poz-93,968 & $4999 \pm 40$ & & 5622 & 5891 & 1 & $-0.5 \pm 0.2$ & index \\
\hline P17-5 & 38.855 & 0.073 & 0.8 & Wood & Lagoonal & Poz-93,804 & $1100 \pm 40$ & & 929 & 1171 & 1 & $0.3 \pm 0.2$ & index \\
\hline P17-7 & 38.857 & 0.061 & -1.6 & Charcoals, peat & Lagoonal & Poz-94,010 & $2970 \pm 35$ & & 3005 & 3231 & 1 & $-2.1 \pm 0.2$ & index \\
\hline P17-3 & 38.861 & 0.055 & -2.6 & Charcoals & Lagoonal & Poz-93,967 & $5180 \pm 40$ & & 5764 & 6095 & 1 & $-3.1 \pm 0.3$ & index \\
\hline P17-8 & 38.876 & 0.088 & -4 & Charcoals & Lagoonal & Beta-460,429 & $6420 \pm 30$ & & 7280 & 7421 & 1 & $-4.5 \pm 0.3$ & index \\
\hline P17-3 & 38.861 & 0.055 & -11 & Charcoals & Lagoonal & Poz-93,699 & $7320 \pm 50$ & & 8011 & 8292 & 1 & $-11.5 \pm 0.3$ & index \\
\hline PDGEST-2 & 38.882 & 0.038 & -17.5 & Charcoals & Lagoonal & Poz-93,698 & $7900 \pm 50$ & & 8594 & 8977 & 1 & $-18 \pm 0.4$ & index \\
\hline PDGEST-2 & 38.882 & 0.038 & -18 & Peat & Lagoonal & Poz-93,965 & $7920 \pm 50$ & & 8605 & 8978 & 1 & $-18.5 \pm 0.4$ & index \\
\hline PDGEST-2 & 38.882 & 0.038 & -18.5 & Charcoals, peat & Lagoonal & Poz-93,966 & $7910 \pm 50$ & & 8598 & 8977 & 1 & $-19 \pm 0.4$ & index \\
\hline P-6 & 38.873 & 0.064 & -0.15 & Peat & Lagoonal & & $1660 \pm 50$ & & 1415 & 1696 & 2 & $-0.55 \pm 0.3$ & index \\
\hline P-6 & 38.873 & 0.064 & -0.4 & Peat & Lagoonal & & $2400 \pm 60$ & & 2340 & 2704 & 2 & $-0.9 \pm 0.3$ & index \\
\hline P-6 & 38.873 & 0.064 & -0.65 & Peat & Lagoonal & & $3250 \pm 100$ & & 3233 & 3703 & 2 & $-1.15 \pm 0.3$ & index \\
\hline P-6 & 38.873 & 0.064 & -0.9 & Peat & Lagoonal & & $3540 \pm 80$ & & 3619 & 4080 & 2 & $-1.4 \pm 0.3$ & index \\
\hline P-7 & 38.864 & 0.045 & -1.9 & Peat & Lagoonal & & $5200 \pm 60$ & & 5761 & 6179 & 2 & $-2.3 \pm 0.3$ & index \\
\hline P-6 & 38.873 & 0.064 & -1.8 & Peat & Lagoonal & & $5330 \pm 90$ & & 5934 & 6283 & 2 & $-2.3 \pm 0.3$ & index \\
\hline P-6 & 38.873 & 0.064 & -2 & Shell & Shoreface & $R-2013$ & $6343 \pm 100$ & $94 \pm 61$ & 6224 & 6726 & 3 & $-2 \pm 0.3$ & marine \\
\hline$P-7$ & 38.864 & 0.045 & -10.9 & Peat & Lagoonal & UBAR-44 & $7790 \pm 110$ & & 8401 & 8977 & 2 & $-11.4 \pm 0.4$ & index \\
\hline $\mathrm{P}-3$ & 38.880 & 0.048 & -15 & Peat & Lagoonal & UBAR-78 & $8300 \pm 170$ & & 8770 & 9580 & 2 & $-15.5 \pm 0.4$ & index \\
\hline$P-1$ & 38.884 & 0.040 & -20 & Peat & Lagoonal & UBAR-77 & $10,120 \pm 460$ & & 10,521 & 12,826 & 4 & $-20.5 \pm 0.4$ & index \\
\hline
\end{tabular}

landward migration $4 \mathrm{~km}$ to the modern shoreline. Unit 3 reaches the modern surface $(0 \mathrm{~m})$ at the position of the sand barrier (PDGEST-7 and PDGEST-2). In the marsh, the contact between the Unit 3 and Unit 4 occurs at $-2.5 \mathrm{~m}$ in P17-3 and $-2 \mathrm{~m}$ in P17-7, P7, PDGEST-6, P6, P4, and P3. Unit 4 reflects a highstand system tract. Colluvial deposits of Unit 5 are intercalated below Unit 4 ( $-2 \mathrm{~m}$ in PDGEST-8 and P17-4) and above (P17-5).

\subsection{Chronostratigraphy}

Nineteen radiocarbon ages were obtained, comprising nine new ones in this study (Table 1). Compared to previous work the particular methodological attention paid to the new samples (i.e. picking up small, up to $200 \mu \mathrm{m}$ in size, identified terrestrial material one by one under a binocular loupe to avoid old carbon contamination) allows for greatly improving the chronological constrain (e.g. reducing error to a maximum of 50 years BP). All samples except one (R-2013) are from terrestrial macroremains (peat leave, charcoal, wood) from Unit 2 and Unit 4. The ${ }^{14} \mathrm{C}$ ages are classified following the methodology of Vacchi et al. (2016) estimating the Relative Sea Level (RSL) elevation based on environmental indicators (Table 1 ). Most of the ${ }^{14} \mathrm{C}$ ages (18 ages) were collected from lagoon environments influenced by marine water, which means a RSL elevation of about $-0.5 \mathrm{~m}$ of the sample depth. One sample from a shoreface facies (Table 1) provides a minimum RSL depth position. The cumulative altimetric error associated to the RSL estimation includes the local tide $(10 \mathrm{~cm})$, levelling $(10 \mathrm{~cm})$, deformation due to coring $(20 \mathrm{~cm})$, and angle deviation $(10 \mathrm{~cm}$ for sample having depth superior to $2 \mathrm{~m}$ ). An error of $40 \mathrm{~cm}$ has been applied for coring/sampling deformation for the previous studies. The RSL vertical errors are comprised between \pm 0.2 and $\pm 0.4 \mathrm{~m}$.

Results indicate that sedimentary infilling took place between 9430

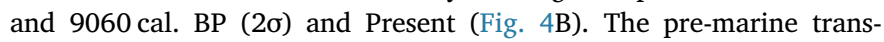
gression lagoon environment (Unit 4) has provided seven ${ }^{14} \mathrm{C}$ ages ranging from $12,830-10,520 \mathrm{cal}$. BP at $-20 \mathrm{~m}$, to $8290-8010 \mathrm{cal}$. BP at $-11 \mathrm{~m}$. The sample UBAR-77, considered with caution because of the large uncertainty (460 years BP), is discarded according to the result of the age-depth model. The modelled age at $-20.5 \mathrm{~m}$ is $9430-9060 \mathrm{cal}$. BP (Fig. 4B) is significantly different from the age obtained at $-11.5 \mathrm{~m}$ (8250-8060 cal. BP). The three samples measured at $-18,-18.5$ and $-19 \mathrm{~m}$ in the same borehole (PDGEST-2) have similar ages ranging

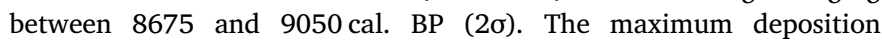

duration of this peat layer is of 375 years, indicating that the sedimentation rate cannot be inferior to $20 \mathrm{~m}$ /year. The maximal sea inland extension ( $4 \mathrm{~km}$ from the modern position) is dated at $7280-7420 \mathrm{cal}$. $\mathrm{BP}$ ( $-4 \mathrm{~m}$ in core P17-8). According to this result, the sea-level rise has been high up to that date with a mean value of $9 \mathrm{~mm}$ /year (Fig. 4B). The second lagoonal phase (Unit 4) developed on the marine sediments of Unit 3 has been dated at $6090-5760$ cal. BP in core P17-3, $6180-5760 \mathrm{cal}$. BP in P7, and 6280-5930 cal. BP in P6. Overlapping ages $(2 \sigma)$ indicate that lagoon development was synchronic at the scale of the basin. By that time, the shoreline position was closed to the modern one, characterised by a sand barrier probably closing, at least partially, the bay of Pego-Oliva. Moreover, age continuity over the Unit 4 indicates that no significant hiatus of sedimentation or abrupt environmental changes occurred from that time. Finally, several colluvial layers (Unit 5) occurred before 7420-7280 cal. BP (P17-8), before 5890-5620 cal. BP (P17-4), and after 1170-930 cal. BP (P17-5). The spatial extent of the fans has never reached Unit 3 indicating that catchment sediment supply has been modest during the Holocene.

Based on these results, the RSL position has been reconstructed for the six key-dates of the morphogenetic evolution at 9030, 8840, 8555, 8095, 7330, $5760 \mathrm{cal}$. BP (Fig. 5A). The shoreline displacement is $7 \mathrm{~km}$ inland in line with the wetland, and $5 \mathrm{~km}$ inland in the northern sector that corresponds respectively to 4 and $2 \mathrm{~km}$ inland compared to the present shoreline. The absolute horizontal shoreline displacement is characterised by a linear relationship and a displacement rate of $180 \mathrm{~m} /$ 50 years (Supplementary material 2).

\section{Discussion}

\subsection{Significance of the early to mid-Holocene reconstructions}

At a global scale, observation and model indicate that the RSL rising rate was almost uniform from 11,650 to 7000 cal. BP (Lambeck et al., 2014). A rising rate of $8 \mathrm{~mm} /$ year has been documented in the Mediterranean (Vacchi et al., 2016), that is in good agreement with the estimated rate at Pego-Oliva of $9 \mathrm{~mm}$ /year (Fig. 4B). Besides, we have shown that peat layer deposition between -18.5 and $-17.5 \mathrm{~m}$ spanned a maximum of 375 years that also fits a rising rate of $9 \mathrm{~mm} /$ year. A sudden slowdown occurred at $7000 \mathrm{cal}$. BP (the best modelled age for the breakpoint is 7150 cal. BP, Supplementary Material 1) with a mean value of $0.6 \mathrm{~mm} / \mathrm{yr}$. In general, the ICE $5 \mathrm{G}-\mathrm{VM} 2$ isostatic model in 

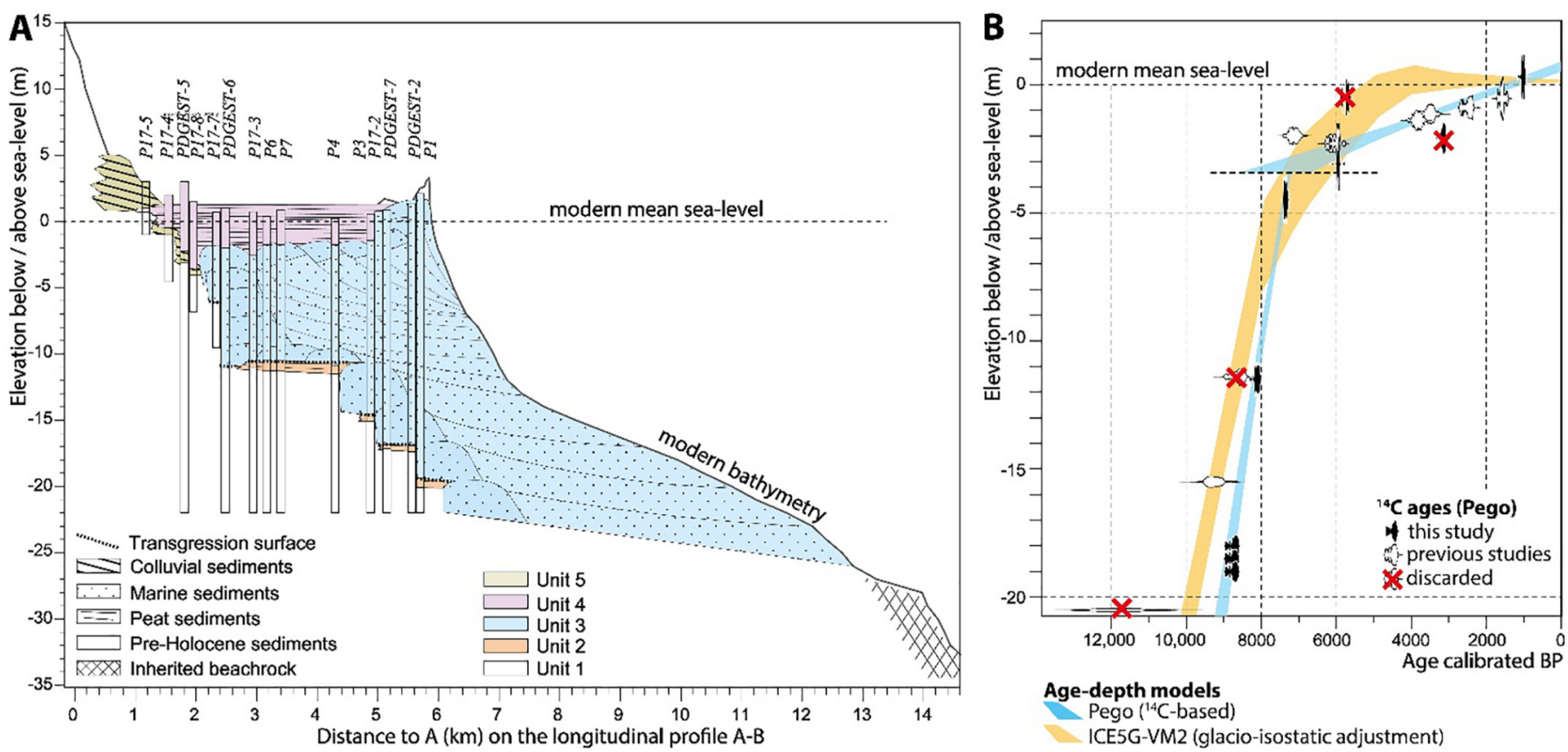

Fig. 4. A) Interpretative sketch of the sediment infilling reported according to the land to sea transect A-B (Fig. 1C) based on 14 boreholes, seismic profile, current topography, and bathymetry. B) Age-depth model calculated from the probabilities density functions of the ${ }^{14} \mathrm{C}$ ages of Pego-Oliva compared to the predicted glacioisostatic adjustment ICE5G-VM2 in the area (Vacchi et al., 2016).

Central Spain (Vacchi et al., 2016; Fig. 4B) and the observations in Pego-Oliva are in good agreement in the Early and Mid-Holocene, while there is a misfit in the Late Holocene (Fig. 4B). This offset is likely to be explained by subsidence (Vacchi et al., 2016), that may be an effect of tectonic and compaction (Marriner et al., 2012). Indeed, the Miocene basement of Pego-Oliva presents normal fault-limited blocks have been responsible for subsidence during the Quaternary at rates of 4 to $7 \mathrm{~mm}$ / year, making conditions for deposition of a $140 \mathrm{~m}$-thick sediment pile (Torres et al., 2014). Besides, during the Holocene, the newly acquired ${ }^{14} \mathrm{C}$ ages having analytical errors greatly reduced compared to previous works (Table 1), indicates that peat layers deposited at $-18 \mathrm{~m}$ and $-11 \mathrm{~m}$ have significant different ages (respectively 8594-8977 cal. BP and 8011-8292 cal. BP) indicating that during the Early Holocene, varying depths of these peat layers cannot be explained by subsidence alone.

The paleogeography reconstructions proposed in Fig. 5A are built on the step backward peat sequence (Unit 2) interpreted as a lagoonal environments subjected to marine influence. Based on a literature review linking environmental context and RSL position, samples carried out in inner or semi-enclosed lagoon sediments are likely to correspond to a mean RSL position of 0 to $-1 \mathrm{~m}$ (Vacchi et al., 2016). A lowering of $1 \mathrm{~m}$ implies a shoreline displacement of $500 \mathrm{~m}$ seaward (Fig. 5A), because projection on the present-day bathymetry implies that bathymetric profile has not changed from that time, an assumption that is easily arguable in context of rocky coast but that is questionable for the soft coasts like Pego-Oliva. Underwater seismic profiles and high-resolution bathymetry carried out in the Gulf of Valencia and at the line with the Pego-Oliva basin have revealed sand wave features at depths ranging from -55 to $-80 \mathrm{~m}$, inferring an RSL position between -30 to - 50 m (Alcántara-Carrió et al., 2013; Albarracín et al., 2013, 2014), probably associated with the Younger Dryas (12,900-11,700 cal. BP; Blockley et al., 2012). Besides, several beachrocks are located from -25 to $-35 \mathrm{~m}$ (Rey and Fumanal, 1996). Beachrocks, as lithified deposits, are generally formed in intertidal or supratidal zones, but without cement analyses, a conservative approach is to estimate a mean RSL range of +2 to $-1 \mathrm{~m}$ (Vacchi et al., 2016). Related to these beachrocks, the mean RSL would have been located between -23 and $-36 \mathrm{~m}$. This depth interval is in agreement with the development of an inner coastline lagoon at $-20 \mathrm{~m}$. Thus, considering the beachrock position (Figs. 1B, 4A), the shoreline could not have been more than $1 \mathrm{~km}$ seaward, arguing that shoreline projections on the present-day bathymetry are relevant (Fig. 5A).

\subsection{Influence of climate on the morphogenetic evolution}

Three main phases of the coastal evolution have been identified at Pego-Oliva during the Early to Mid-Holocene (Fig. 5B). From 9500 to $8200 \mathrm{cal}$. BP, the retrogradational architecture is characterised by four steps of shallow inner lagoon deposits. In Iberian Mediterranean, similar isolated ages have been obtained for pre-marine transgression brackish lagoon deposits, dated at 10,555-9665 cal. BP in Xàbia (Viñals et al., 1993), at 8320-8180 cal. BP and 8530-8280 cal. BP in the Albufera (Carmona and Ruiz, 2011; Carmona et al., 2016). A similar timing of the backstepping sequence has been found in the Rhone delta at $9800-8200 \mathrm{cal}$. BP (Amorosi et al., 2013a), in Tuscany at 9600-7880 cal. BP (Amorosi et al., 2013b), in the Adriatic Sea at 9200-7700 cal. BP (Amorosi et al., 2017). Retrogradational coastal sequences are in accordance with the high global RSL rising rate of the end of the last glaciation relative to the Laurentide ice sheet dismantling (Roy and Peltier, 2018). From 8200 to $7300 \mathrm{cal}$. BP, the backward shoreline migration reached a maximal inland position leading to the disappearance of the former inner lagoon. The marine transgression inland has been dated in Xàbia, in the Pego vicinity at 7570-6865 cal. BP (Viñals and Fumanal, 1995). In the Valencian gulf, the maximal inland position of the beach dated at 7500-7200 cal. BP (Carmona and Ruiz, 2011) has also been associated with the desiccation of several coastal lagoons (Marco-Barba et al., 2013; Blázquez et al., 2017). In very detailed sequences, this evolution has been constrained at $7700-7000 \mathrm{cal}$. BP in Po delta (Amorosi et al., 2017) and at 7840-7000 cal. BP in Tuscan (Amorosi et al., 2013b). This period corresponds to the complete melting of former ice-sheets that occurred around 8000-7500 cal. BP (Roy and Peltier, 2018). Following the maximum of inland flooding, barrier construction led to the formation of an inner coastal lagoon since $5800 \mathrm{cal}$. BP in Pego-Oliva. In the Mediterranean, the RSL global stabilisation has resulted in the formation of highstand system tracts related to seaward progradation of river 

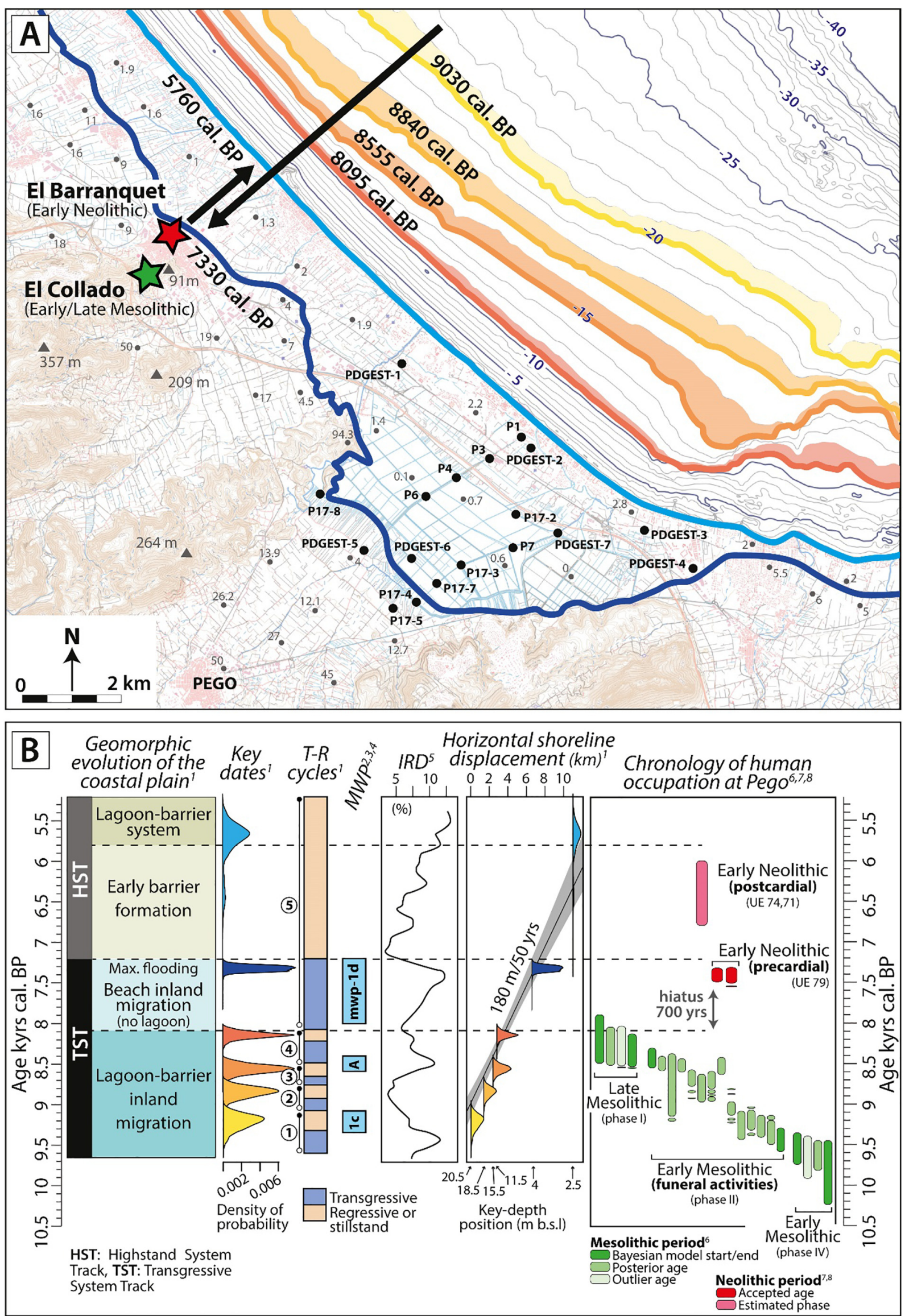
Fig. 5. A) Projected sea-level position at selected key-dates (best age cal. BP) of the morphogenetic evolution on the current elevation contours, that includes the vertical error estimate. The two archaeological sites are shown by stars. The thick black arrows point out the kinematic of shoreline evolution through time. B) Comparison of the coastal morphogenetic evolution at Pego-Oliva with key-dates of the morphogenetic evolution and a simplified representation of transgressive and stillstand phases (this study ${ }^{1}$ ), with phases of freshwater meltwater pulses (MWP) from Smith et al. (2011) ${ }^{3}$ and Liu et al. (2004) ${ }^{4}$, and with the Ice-Rafted Debris

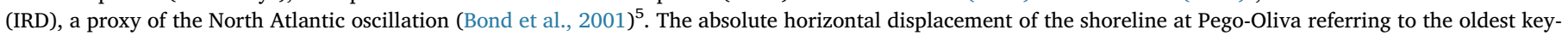
date (yellow line in A) is represented according to the best age-distance model (black line) and its 95\% confidence (grey envelope). Morphogenetic evolution of the coast is compared to the chronology of the Mesolithic and Neolithic settlements located in the study area ( ${ }^{6}$ Fernández-López de Pablo, 2016 - Bayesian chronostratigraphic model of the ${ }^{14} \mathrm{C}$ ages; ${ }^{7}$ Bernabeu et al., 2009 - individual calibrated ${ }^{14} \mathrm{C}$ ages from the Precardial pottery phase, ${ }^{8}$ Esquembre-Bebia et al., $2008-$ estimated age of the Postcardial pottery phase). Contour colours in A of the selected key-dates refer to colours of the age probability distributions in B. (For interpretation of the references to colour in this figure legend, the reader is referred to the web version of this article.)

deltas (Anthony et al., 2014; Amorosi et al., 2013a), coastal barrier system constructions and large development of lagoon environments (Marco-Barba et al., 2013; Blázquez et al., 2017; Melis et al., 2017; Melis et al., 2018; Pascucci et al., 2018).

In the Mediterranean, a large range of literature proposes a causal link between coastal evolution and the sub-millennial North Atlantic Oscillation for the last 7000 years (Zazo et al., 2008; Amorosi et al., 2017; Pascucci et al., 2018), because highstand systems tract has allowed for the recording of small-amplitude regressive and transgressive cycles (Fruergaard et al., 2015). Fewer data exist during the Early to Mid-Holocene (Amorosi et al., 2013a; Amorosi et al., 2017). A cause of RSL variability can be linked to thermal expansion of water masses related to sea temperature (González and Törnqvist, 2009). However, as western Mediterranean Sea surface temperatures are relatively stable over the Early Holocene (Jalali et al., 2016), it seems unlikely that thermal expansion/contraction explains the evolution at Pego-Oliva. Another explanation could be related to the alternation of pulse and pause of the RSL. Five transgressive phases have been recorded at PegoOliva (Fig. 5B) at $9500\left(n^{\circ} 1\right), 9100-9000\left(n^{\circ} 2\right), 8750-8650\left(n^{\circ} 3\right)$, $8450-8200\left(\mathrm{n}^{\circ} 4\right)$, and $8100-7300 \mathrm{cal}$. BP $\left(\mathrm{n}^{\circ} 5\right)$. The phases 4 and 5 may match with meltwater pulses identified in the North Atlantic (Nesje et al., 2004; Smith et al., 2011) (Fig. 5B). A linkage between North Atlantic has been suggested in the North-East Mediterranean where drops in water salinity were caused by enhancing outflow from the Black-Sea during its high level phases (Herrle et al., 2018). Correspondence between morphogenetic evolution and meltwater pulses suggests a potential linkage although it remains unclear whether they could have been significant enough to be recorded compared to the massive ice sheets dismantling of the Early Holocene. Finally, sand spit progradation and lagoon formation may be influenced by climate variability by increasing sediment supply entering into the system from rivers and its redistribution along the coast through intensification of longshore drift velocity. Iberian Mediterranean river activity presents an opposite pattern to Pego-Oliva lagoon formation that does not argue for an increase of the sediment supply (Thorndycraft and Benito, 2006). Besides, a prolonged period of deep-sea current intensification offshore of the Balearic island is recorded between 9500 and $8000 \mathrm{cal}$. BP (Frigola et al., 2007), concomitant to higher ice-rafted debris in the Northern Atlantic (Bond et al., 2001). Together, it argues that cold and dry climate events may have locally increased wind intensity, and thus longshore drift velocity. For example, the $8200 \mathrm{cal}$. BP climate event has been depicted as an aridity crisis in the regional continental archives (Morellón et al., 2008; Jones et al., 2018).

\subsection{Socio-ecological adaptation during the early to mid-Holocene}

The area of Pego-Oliva has been occupied by prehistoric communities during the Early and Mid-Holocene (Fumanal et al., 1993b). In order to investigate the influence of coastal evolution on human occupation patterns, we have compared the results of this study with the chronological and occupational evidences of the Mesolithic site of El Collado and the Neolithic site of El Barranquet, both located $5 \mathrm{~km}$ north of Pego-Oliva (Fig. 5A and B). The presence of inner coastal lagoons, dated from 9500 to $8200 \mathrm{cal}$. BP was concomitant to the occupation of El Collado site during both the Early and the Late Mesolithic
(Fernández-López de Pablo, 2016). Shallow brackish lagoonal waters in the site vicinity have certainly offered a diversity of resources, including marine mollusc and fish, as it has been reported along the Early Mesolithic levels of El Collado sequence (Fernández-López de Pablo and Gabriel, 2016). Indeed, among marine molluscs the assemblages were noticeably dominated by Cerastoderma glaucum, a marine bivalve inhabiting soft sandy to muddy substrates of brackish lagoon waters and low-energy environment (Ivell, 1979). Marine resources collected in this coastal environment were relevant for the Early Mesolithic communities occupying this area, as independently suggested by the paleodietary isotope analyses on human remains, indicative of an intake of proteins of marine origin of 25\% (García Guixé et al., 2006).

It is worth noting that malacological assemblages have shown diachronic differences in the intensity of shellfish exploitation. The two Early Mesolithic phases display a more intense exploitation of shellfish and fish compared to the Late Mesolithic layer in which a significant decrease of the frequency and size of $C$. glaucum valves are documented at about 8500 cal. BP (Fernández-López de Pablo and Gabriel, 2016). Our results suggest that the reduction of the shellfish productivity was driven by a contraction of the coastal lagoons associated with the sealevel rise. Interestingly, the presence of a short Late Mesolithic occupational interval postdating the chronological span of the funerary activity suggests a change in the settlement pattern probably toward more ephemeral occupations. At this moment, our results date the disappearance of the lagoon biotope right after $8200 \mathrm{cal}$. BP at PegoOliva, one of the shellfish collecting areas exploited over generations during the Mesolithic. Moreover, the absence of pre-transgressive lagoonal deposits in a $20 \mathrm{~km}$ radius (Fumanal et al., 1993b) reinforces the interpretation of a major reduction of these habitats in the settlement's vicinity. In addition of loss of biota caused by marine flooding, the backward migration of the shoreline is likely to have also reduced the spatial extension of the colluvial glacis favourable for hunting terrestrial game. Altogether, it is likely that these changes have dramatically reduced the carrying capacity of the ecosystem rendering this area less attractive to forager communities.

The environmental mutation consecutive to the global sea-level rise negatively impacted the Late Mesolithic subsistence and settlement patterns, probably driving to a significantly lower occupational intensity (even depopulation) of this coastal area. Indeed, the end of the occupation at El Collado site coincides with a spatial re-organization of the Late Mesolithic settlement networks and the lack of archaeological sites dated in the adjacent valleys (Gómez-Puche and Fernández-López de Pablo, 2015). The subsequent Final Mesolithic occupations, that have been dated between 7900 and 7700 cal. BP, occurred as inland patches about $60 \mathrm{~km}$ away from the coast (Fernández-López de Pablo et al., 2013; García-Puchol et al., 2018). After 700 years (Fig. 5B) from the last dated Mesolithic occupations, the area of Pego-Oliva witnessed the arrival of the first farming communities as represented by the Earliest Neolithic phase of El Barranquet site. This dynamic supports the model of pioneer maritime colonization in Eastern Iberia (Zilhão, 2001; Isern et al., 2017) implying a leap-frog dispersal modality by which the earliest farmers established their settlements in unoccupied areas by Final Mesolithic (Bernabeu and Martí, 2014; Bernabeu Aubán et al., 2017). Preliminary data on the mollusc assemblages of El Barranquet (Luján Navas, 2016) suggests that a major change in the 
relative abundance of marine bivalves collected for consumption occurred between the two Early Neolithic phases. C. glaucum species dominate the Impressa phase whereas the Postcardial layers show a higher representation of Glycimeris glycymeris. This shift in favour of infralittoral species in the archaeological record is in agreement with the environmental reconstruction that shows that the beachfront was getting closer to the site, reaching its proximal position at $7300 \mathrm{cal}$. BP (Fig. 5A), right after the Precardial phase and during the Postcardial (Fig. 5B). Altogether, these results suggest a lose link between nearby ecosystems and subsistence choices, arguing that the Neolithic communities have adapted species collection to the resource locally available.

Based on the Early to Mid-Holocene geomorphological reconstructions at Pego-Oliva, a vertical sea-level rising rate of $50 \mathrm{~cm} / 50$ years has been estimated (Fig. 4B); that once translated into paleogeographical reconstructions (Fig. 5A) allows to estimate a horizontal displacement rate of the shoreline of $180 \mathrm{~m} / 50$ years (Fig. 5B). Both vertical and horizontal shoreline displacement rates are rapid enough to be perceptible by human communities, at a level of 1 to 2 generations only, as it has been also suggested during the Early Holocene inundation of North-Western Europe (Sturt et al., 2013). More than the vertical rate, the rapidity with which the shoreline came closer may have also increased vulnerability to short high-energy marine events (Leary, 2009). Taking into account that Mesolithic occupation of El Collado has spanned 1022-1965 years (Fernández-López de Pablo, 2016); this context of highly changing landscapes must have been perceptible by the last hunter-gatherers. Conneller et al. (2016) have rather suggested that landscapes "produced and continually reproduced by sea-level rise" may have in fact encouraged exploitation. Nevertheless, the adaptive flexibility of these populations seems to have faced very important environmental changes at $8200 \mathrm{cal}$. BP, with the extinction of previously exploited ecosystems, and abandonment of the El Collado implantation. The hypothesis of a convergence of environmental events rendering populations more sensitive could be made (Leary, 2009). Based on this case-study, it may have resulted in the superimposition of the repercussion of the long-term sea-level rise on the coastal geomorphology and ecosystems, with the abrupt aridity event that has occurred at $8200 \mathrm{cal}$. BP. Finally, our results show that once the last foragers left, a new population with a different cultural baggage (first Neolithic) settled in the same environment. It clearly comes out that the perception of this same environment has been different for populations with different cultural backgrounds. Thus, this case-study of past Human-environment interactions runs counter to subjective valuations of ecosystems in terms of services or constraints for society (e.g. Costanza et al., 2014). We plead for a more thorough consideration of the local and regional scales of socio-ecological interactions and reorganisations when investigating resilience and adaptive strategies of societies to global changes past and present (Redman, 2005; Van de Noort, 2011).

\section{Conclusions}

This paper investigated how coastal evolution affected settlement and subsistence patterns during the Mesolithic-Neolithic transition. Based on multiple sediment coring in the Pego-Oliva basin, new sedimentological analyses and ${ }^{14} \mathrm{C}$ dates combined with previous biological works, we have reconstructed the geometry of the sedimentary facies and the timing of depositions throughout the Holocene. Three main periods have been identified; from 9500 to $8200 \mathrm{cal}$. BP, the stepwise inland migration of the coastline consecutive to sea-level rise has led to the deposition of four individual peat layers at 20.5, 18.5, 15.5 and $11.5 \mathrm{~m}$ below the present sea-level. We interpret this stepwise transgression as a result of periods of acceleration of barrier construction associated with higher drift velocity linked with a drier climate (e.g. at $8200 \mathrm{cal}$. BP). The transgressive phases, that have been dated at 9500 , 9100-9000, 8750-8650, 8450-8200, and 8100-7300 cal. BP, match with some of the phases of meltwater pulses in the North Atlantic. From 8200 to 7200 cal. BP, the pursuit of the backward migration of the coastline provokes the disappearance of the coastal lagoons. The maximum of the marine transgression, $2 \mathrm{~km}$ inland, is dated at $7200 \mathrm{cal}$. BP. This timing is very similar to other Mediterranean records. From 7200 cal. BP to Present: following sea-level stabilisation, sand barrier reconstruction promoted the basin closing, inducing a return to a coastal barrier-lagoon system at $5800 \mathrm{cal}$. BP, when the shoreline position was similar to the modern's one.

Results have been compared to the archaeological records of the same area. The interdisciplinary approach allowed us to interpret that: 1) the long-lasting occupation of the Mesolithic shell midden of El Collado has corresponded to the period of presence of coastal lagoon, offering a diversity of marine resource available, easily exploited in the inter-tidal shallow and brackish waters; 2) the spatial contraction of the coastal lagoon has corresponded to the sharp drop in Cerastoderma glaucum species during the Late Mesolithic, suggesting that the marine resource depletion primarily occurred because of a decrease in marine resource productivity; 3 ) the abandonment of the El Collado site and the 700 years' temporal hiatus observed between the Mesolithic and Neolithic implantations is likely to be explained by the consequence of the disappearance of the coastal lagoon and the formerly exploited biotopes at $8200 \mathrm{cal}$. BP, that may have been together with the aridity crisis occurring at that time factors of depopulation of this area; 4) the maximal inland transgression of the sea at $7200 \mathrm{cal}$. BP has been contemporary of a shift toward more infralittoral marine shell assemblages during the Postcardial phase at El Barranquet site suggesting that Early Neolithic populations have successfully adapted to rapidly changing environments.

We concluded that prehistoric communities with different cultural baggage have had different perceptions of their environment, questioning subjective valuations of ecosystems in terms of services or costs for society, and emphasising the importance of examining socio-ecological reorganisations at the local and regional scale when investigating adaptive strategy to global changes.

\section{Funding}

This work is a contribution to the project MedCoRes (ref. 704822) "Mediterranean Coastal Resources: benefits and constraints for Prehistoric hunters-gatherers" funded by the Marie Sklodowska-Curie Action (European Union) led by E. Brisset (IPHES, URV) and has benefited of the support of the AGAUR agency (SGR 836 Research Group) and the MINECO project Postglacial-Med (HAR2017-88503-P). J. Fernández-López de Pablo (IPHES, URV) is supported by the MINECO Grant IEDI-2017-00889.

\section{Acknowledgments}

We are grateful to Helena Velayos Mayo and Javier Muñoz of the Litoteca of the Instituto Geológico y Minero de España (IGME) to have kindly facilitated consultation and sampling of the archives. We also thank Malebogo Mvimi (MNHN, IPHES) for her help in the English editing, and two anonymous reviewers for their insightful comments.

\section{Appendix A. Supplementary data}

Supplementary data to this article can be found online at https:// doi.org/10.1016/j.gloplacha.2018.07.016.

\section{References}

Albarracín, S., Alcántara-Carrió, J., Barranco, A., García, M.J.S., Bouzas, Á.F., Salgado, J.R., 2013. Seismic evidence for the preservation of several stacked Pleistocene coastal barrier/lagoon systems on the Gulf of Valencia continental shelf (western Mediterranean). Geo-Mar. Lett. 33, 217-223. https://doi.org/10.1007/s00367-012- 
0315-x.

Albarracín, S., Alcántara-Carrió, J., Montoya-Montes, I., Fontán-Bouzas, Á., Somoza, L., Amos, C.L., Salgado, J.R., 2014. Relict sand waves in the continental shelf of the Gulf of Valencia (Western Mediterranean). J. Sea Res. 93, 33-46. https://doi.org/10. 1016/j.seares.2013.12.014.

Alcántara-Carrió, J., Albarracín, S., Montes, I.M., Flor-Blanco, G., Bouzas, Á.F., Salgado, J.R., 2013. An indurated Pleistocene coastal barrier on the inner shelf of the Gulf of Valencia (western Mediterranean): evidence for a prolonged relative sea-level stillstand. Geo-Mar. Lett. 33, 209-216. https://doi.org/10.1007/s00367-012-0316-9.

Amorosi, A., Rossi, V., Vella, C., 2013a. Stepwise post-glacial transgression in the Rhône Delta area as revealed by high-resolution core data. Palaeogeogr. Palaeoclimatol. Palaeoecol. 374, 314-326. https://doi.org/10.1016/j.palaeo.2013.02.005.

Amorosi, A., Rossi, V., Sarti, G., Mattei, R., 2013b. Coalescent valley fills from the late Quaternary record of Tuscany (Italy). Quat. Int. 288, 129-138. https://doi.org/10. 1016/j.quaint.2011.10.015.

Amorosi, A., Bruno, L., Campo, B., Morelli, A., Rossi, V., Scarponi, D., Hong, W., Bohacs, K.M., Drexler, T.M., 2017. Global sea-level control on local parasequence architecture from the Holocene record of the Po Plain, Italy. Mar. Petrol. Geol. Sedimentol. Italy 87, 99-111. https://doi.org/10.1016/j.marpetgeo.2017.01.020.

Anthony, E.J., Marriner, N., Morhange, C., 2014. Human influence and the changing geomorphology of Mediterranean deltas and coasts over the last $6000 y e a r s:$ from progradation to destruction phase? Earth Sci. Rev. 139, 336-361. https://doi.org/10. 1016/j.earscirev.2014.10.003.

Aparicio, P., 2014. El Collado, in: Pleistocene and Holocene Hunter Gatherers in Iberia and the Gibraltar Strait: The Current Archaeological Record. University of Burgos, Sala Ramos R, pp. 338-344.

Bailey, G., 2004. World prehistory from the margins: the role of coastlines in human evolution. J. Interdisc. Stud. Hist. Archaeol. 39-50.

Ballesteros Navarro, B., Domínguez Sánchez, J.A., Díaz-Losada, E., Garíca Menéndez, O., 2009. Zonas húmedas mediterráneas y acuíferos asociados. Condicionantes hidrogeológicos del Marjal de Pego-Oliva (Alicante-Valencia). Bol. Geol. Min. 120, 459-478.

Benjamin, J., Rovere, A., Fontana, A., Furlani, S., Vacchi, M., Inglis, R.H., Galili, E., Antonioli, F., Sivan, D., Miko, S., Mourtzas, N., Felja, I., Meredith-Williams, M., Goodman-Tchernov, B., Kolaiti, E., Anzidei, M., Gehrels, R., 2017. Late Quaternary sea-level changes and early human societies in the central and eastern Mediterranean Basin: an interdisciplinary review. Quat. Int. 449, 29-57. https://doi.org/10.1016/j. quaint.2017.06.025.

Bernabeu Aubán, J., García Puchol, O., Orozco-Köhler, T., 2017. New insights relating to the beginning of the Neolithic in the eastern Spain: Evaluating empirical data and modelled predictions. Quat. Int. https://doi.org/10.1016/j.quaint.2017.03.071.

Bernabeu, J., Martí, B., 2014. The first agricultural groups in the Iberian peninsula. In: Manen, C., Perrin, T., Guilaine, J. (Eds.), The Neolithic Transition in the Mediterranean, pp. 419-438.

Bernabeu, J., Molina, L.L., Esquembre-Bebia, M.A., Ortega, J.R., Boronat, J., 2009. In: D'ailleurs, De Méditerranée et, Jean Guilaine, Mélanges Offerts a (Eds.), La cerámica impresa mediterránea en el origen del Neolítico de la península ibérica. Collectif, Toulouse, pp. 83-95.

Blaauw, M., 2010. Methods and code for "classical" age-modelling of radiocarbon sequences. Quat. Geochronol. 5, 512-518. https://doi.org/10.1016/j.quageo.2010.01. 002.

Blázquez, A.M., Rodríguez-Pérez, A., Torres, T., Ortiz, J.E., 2017. Evidence for Holocene sea level and climate change from Almenara marsh (western Mediterranean). Quat. Res. 88, 206-222. https://doi.org/10.1017/qua.2017.47.

Blockley, S.P.E., Lane, C.S., Hardiman, M., Rasmussen, S.O., Seierstad, I.K., Steffensen, J.P., Svensson, A., Lotter, A.F., Turney, C.S.M., Bronk Ramsey, C., 2012. Synchronisation of palaeoenvironmental records over the last 60,000 years, and an extended INTIMATE event stratigraphy to 48,000 b2k. Quat. Sci. Rev. 36, 2-10. https://doi.org/10.1016/j.quascirev.2011.09.017.

Bond, G., Kromer, B., Beer, J., Muscheler, R., Evans, M.N., Showers, W., Hoffmann, S., Lotti-Bond, R., Hajdas, I., Bonani, G., 2001. Persistent solar influence on North Atlantic climate during the holocene. Science 294, 2130-2136. https://doi.org/10. 1126/science.1065680.

Burnett, M.R., August, P.V., Brown, J.H., Killingbeck, K.T., 1998. The influence of geomorphological heterogeneity on biodiversity I. A patch-scale perspective. Conserv. Biol. 12, 363-370. https://doi.org/10.1111/j.1523-1739.1998.96238.x.

Carmona, P., Ruiz, J.M., 2011. Historical morphogenesis of the Turia River coastal flood plain in the Mediterranean littoral of Spain. Catena 86, 139-149. https://doi.org/10. 1016/j.catena.2010.12.006.

Carmona, P., Ruiz-Pérez, J.-M., Blázquez, A.-M., López-Belzunce, M., Riera, S., Orengo, H., 2016. Environmental evolution and mid-late Holocene climate events in the Valencia lagoon (Mediterranean coast of Spain). The Holocene 26, 1750-1765. https://doi.org/10.1177/0959683616645940.

Colonese, A.C., Mannino, M.A., Bar-Yosef Mayer, D.E., Fa, D.A., Finlayson, J.C., Lubell, D., Stiner, M.C., 2011. Marine mollusc exploitation in Mediterranean prehistory: an overview. Quat. Int. Shell Midden Res. 239, 86-103. https://doi.org/10.1016/j. quaint.2010.09.001.

Colonese, A.C., Lo Vetro, D., Landini, W., Di Giuseppe, Z., Hausmann, N., Demarchi, B., D'Angelo, C., Leng, M.J., Incarbona, A., Whitwood, A.C., Martini, F., 2018. Late Pleistocene-Holocene coastal adaptation in central Mediterranean: snapshots from Grotta d'Oriente (NW Sicily). Quat. Int. https://doi.org/10.1016/j.quaint.2018.06. 018.

Conneller, C., Bates, M., Bates, R., Schadla-Hall, T., Blinkhorn, E., Cole, J., Pope, M., Scott, B., Shaw, A., Underhill, D., 2016. Rethinking human responses to sea-level rise: the Mesolithic occupation of the channel islands. Proc. Prehist. Soc. 82, 27-71. https://doi.org/10.1017/ppr.2016.1.
Costa, L.-J., V., J.-D., Bocherens, H., Desse-Berset, N., Heinz, C., (de) L., F., Magdeleine, J., R., M.P., Thiébault, S., Tozzi, C., 2003. Early settlement on Tyrrhenian islands (8th millennium cal. BC): Mesolithic adaptation to local resources in Corsica and Northern Sardinia. UISPP, Stockholm, Denmark, pp. 3-10.

Costanza, R., de Groot, R., Sutton, P., van der Ploeg, S., Anderson, S.J., Kubiszewski, I., Farber, S., Turner, R.K., 2014. Changes in the global value of ecosystem services. Glob. Environ. Chang. 26, 152-158. https://doi.org/10.1016/j.gloenvcha.2014.04. 002.

Currás, A., Ghilardi, M., Peche-Quilichini, K., Fagel, N., Vacchi, M., Delanghe, D., Dussouillez, P., Vella, C., Bontempi, J.M., Ottaviani, J.-C., 2017. Reconstructing past landscapes of the eastern plain of Corsica (NW Mediterranean) during the last 6000 years based on molluscan, sedimentological and palynological analyses. $\mathrm{J}$. Archaeol. Sci. Rep. 12, 755-769. https://doi.org/10.1016/j.jasrep.2016.09.016.

Dolez, L., Salel, T., Bruneton, H., Colpo, G., Devillers, B., Lefèvre, D., Muller, S.D., Sanchez, C., 2015. Holocene palaeoenvironments of the Bages-Sigean lagoon (France). Geobios 48, 297-308. https://doi.org/10.1016/j.geobios.2015.05.002.

Dupont, C., Tresset, A., Desse-Berset, N., Gruet, Y., Marchand, G., Schulting, R., 2009. Harvesting the seashores in the late mesolithic of northwestern Europe: a view from Brittany. J. World Prehist. 22, 93-111. https://doi.org/10.1007/s10963-009-9017-3.

Dupré, M., Fumanal, M.P., Sanjaume, E., Santisteban, C., Usera, J., Viñals, M.J., 1988. Quaternary evolution of the Pego coastal lagoon (Southern Valencia, Spain). Palaeogeogr. Palaeoclimatol. Palaeoecol. Quat. Coastal Changes 68, 291-299. https://doi.org/10.1016/0031-0182(88)90046-6.

Erlandson, J.M., 2001. The archaeology of aquatic adaptations: paradigms for a new millennium. J. Archaeol. Res. 9, 287-350. https://doi.org/10.1023/ A:1013062712695.

Esquembre-Bebia, M.A., de Soler, J.D.B., Maestre, F.J.J., Hernández, F.J.M., Navas, A.L., de Pablo, J.F.L., Valle, R.M., Eres, M.P.I., García, C.F., Pastor, R.R., Pérez, J.R.O., 2008. El yacimiento neolítico del Barranquet de Oliva (Valencia). Presented at the IV Congreso del Neolítico Peninsular, Museo Arqueológico de Alicante. pp. 183-190.

Fernández-López de Pablo, J., 2016. The timing of postglacial coastal adaptations in Eastern Iberia: a Bayesian chronological model for the El Collado shell midden (Oliva, Valencia, Spain). Quat. Int. 407, 94-105. https://doi.org/10.1016/j.quaint.2015.10. 077.

Fernández-López de Pablo, J., Gabriel, S., 2016. El Collado shell midden and the exploitation patterns of littoral resources during the Mesolithic in the Eastern Iberian Peninsula. Quat. Int. 407, 106-117. https://doi.org/10.1016/j.quaint.2015.11.100.

Fernández-López de Pablo, J., Salazar-García, D.C., Subirà-Galdacano, M.E., Roca De Togores, C., Gómez-Puche, M., Richards, M.P., Esquembre-Bebiá, M.A., 2013. Late Mesolithic burials at casa corona (Villena, Spain): direct radiocarbon and palaeodietary evidence of the last forager populations in Eastern Iberia. J. Archaeol. Sci. 40, 671-680. https://doi.org/10.1016/j.jas.2012.09.005.

Fontana, A., Vinci, G., Tasca, G., Mozzi, P., Vacchi, M., Bivi, G., Salvador, S., Rossato, S., Antonioli, F., Asioli, A., Bresolin, M., Di Mario, F., Hajdas, I., 2017. Lagoonal settlements and relative sea level during bronze age in northern Adriatic: Geoarchaeological evidence and paleogeographic constraints. Quat. Int. 439, 17-36. https://doi.org/10.1016/j.quaint.2016.12.038.

Frigola, J., Moreno, A., Cacho, I., Canals, M., Sierro, F.J., Flores, J.A., Grimalt, J.O., Hodell, D.A., Curtis, J.H., 2007. Holocene climate variability in the western Mediterranean region from a deepwater sediment record. Paleoceanography 22. https://doi.org/10.1029/2006PA001307.

Fruergaard, M., Møller, I., Johannessen, P.N., Nielsen, L.H., Andersen, T.J., Nielsen, L., Sander, L., Pejrup, M., 2015. Stratigraphy, evolution, and controls of a Holocene transgressive-regressive Barrier Island under changing sea level: Danish North Sea coast controls on barrier-island evolution. J. Sediment. Res. 85, 820-844. https://doi. org $/ 10.2110 /$ jsr.2015.53.

Fumanal, M.P., Mateu, G., Rey, J., Somoza, L., Viñals, M.J., 1993a. Las unidades morfosedimentarias cuaternarias del litoral del Cap de la Nau (Valencia-Alicante) y su correlación con la plataforma continental. Estudios sobre Cuaternario 53-64.

Fumanal, M.P., Viñals, M.J., Ferrer, C., Aura, E., Bernabeu, J., Casabó, J., Gisbert, J., Sentí, M.A., 1993b. Litoral y poblamiento en el litoral valenciano durante el Cuaternario reciente: Cap de Cullera-Puntal de Moraira. Estudios sobre Cuaternario 249-259.

García Guixé, E., Richards, M.P., Subirà, M.E., 2006. Palaeodiets of humans and fauna at the Spanish mesolithic site of El Collado. Curr. Anthropol. 47, 549-557. https://doi. org $/ 10.1086 / 504170$.

García-Puchol, O., McClure, S.B., Juan-Cabanilles, J., Diez-Castillo, A.A., BernabeuAubán, J., Martí-Oliver, B., ... 2018. Cocina cave revisited: Bayesian radiocarbon chronology for the last hunter-gatherers and first farmers in Eastern Iberia. Quaternary International 472, 259-271.

Gibaja, J.F., Subirà, M.E., Terradas, X., Santos, F.J., Agulló, L., Gómez-Martínez, I., Allièse, F., de Pablo, J.F.-L., 2015. The emergence of mesolithic cemeteries in SW Europe: insights from the El Collado (Oliva, Valencia, Spain) radiocarbon record. PLoS One 10, e0115505. https://doi.org/10.1371/journal.pone.0115505.

Gómez-Puche, M., Fernández-López de Pablo, J., 2015. AMS radiocarbon Chronology of Late Mesolithic Sites in the Upper Vinalopo Valley (Eastern Iberia). In: Bicho, Nuno, Detry, Cleia, Douglas Price, T., Cunha, Eugénia (Eds.), The 150th Anniversary of the Discovery of Mesolithic Shell Middens, pp. 109-124.

González, J.L., Törnqvist, T.E., 2009. A new Late Holocene sea-level record from the Mississippi Delta: evidence for a climate/sea level connection? Quat. Sci. Rev. Quat. Ice Sheet Ocean Interactions Landsc. Res. 28, 1737-1749. https://doi.org/10.1016/j. quascirev.2009.04.003.

Goude, G., Willmes, M., Wood, R., Courtaud, P., Leandri, F., Cesari, J., Grün, R., 2017. New insights into mesolithic human diet in the mediterranean from stable isotope analysis: the sites of Campu Stefanu and Torre d'Aquila, Corsica. Int. J. Osteoarchaeol. 27, 707-714. https://doi.org/10.1002/oa.2578. 
Herrle, J.O., Bollmann, J., Gebühr, C., Schulz, H., Sheward, R.M., Giesenberg, A., 2018. Black Sea outflow response to Holocene meltwater events. Sci. Rep. 8, 4081. https:// doi.org/10.1038/s41598-018-22453-Z.

Isern, N., Zilhão, J., Fort, J., Ammerman, A.J., 2017. Modeling the role of voyaging in the coastal spread of the Early Neolithic in the West Mediterranean. PNAS 114, 897-902. https://doi.org/10.1073/pnas.1613413114.

Ivell, R., 1979. The biology and ecology of a brackish lagoon bivalve, C. glaucum, in Lago Lungo, Italy. J. Molluscan Stud. 45, 364-382.

Jakobsson, M., Pearce, C., Cronin, T.M., Backman, J., Anderson, L.G., Barrientos, N., Björk, G., Coxall, H., de Boer, A., Mayer, L.A., Mörth, C.-M., Nilsson, J., Rattray, J.E., Stranne, C., Semiletov, I., O'Regan, M., 2017. Post-glacial flooding of the Bering Land Bridge dated to $11 \mathrm{cal} \mathrm{ka} \mathrm{BP}$ based on new geophysical and sediment records. Clim. Past 13, 991-1005. https://doi.org/10.5194/cp-13-991-2017.

Jalali, B., Sicre, M.-A., Bassetti, M.-A., Kallel, N., 2016. Holocene climate variability in the North-Western Mediterranean Sea (Gulf of Lions). Clim. Past 12, 91-101. https://doi. org/10.5194/cp-12-91-2016.

Jones, S.E., Burjachs, F., Ferrer-García, C., Giralt, S., Schulte, L., Fernández-López De Pablo, J., 2018. A multi-proxy approach to understanding complex responses of saltlake catchments to climate variability and human pressure: a Late Quaternary case study from south-eastern, Spain. Quat. Sci. Rev. 184, 201-223. https://doi.org/10. 1016/j.quascirev.2017.12.015

Lambeck, K., Rouby, H., Purcell, A., Sun, Y., Sambridge, M., 2014. Sea level and global ice volumes from the Last Glacial Maximum to the Holocene. PNAS 111, 15296-15303. https://doi.org/10.1073/pnas.1411762111.

Leary, J., 2009. Perceptions of and responses to the Holocene flooding of the north sea lowlands. Oxf. J. Archaeol. 28, 227-237. https://doi.org/10.1111/j.1468-0092. 2009.00326.x.

Liu, J.P., Milliman, J.D., Gao, S., Cheng, P., 2004. Holocene development of the Yellow River's subaqueous delta, North Yellow Sea. Mar. Geol. 209, 45-67. https://doi.org/ 10.1016/j.margeo.2004.06.009.

Luján Navas, A., 2016. Aprovechamiento y gestión de recursos malacológicos marinos en la fachada Mediterránea de la Peninsula Ibérica durante la Prehistoria reciente. Universidad de Alicante, Spain.

Mannino, M.A., Thomas, K.D., Leng, M.J., Di Salvo, R., Richards, M.P., 2011. Stuck to the shore? Investigating prehistoric hunter-gatherer subsistence, mobility and territoriality in a Mediterranean coastal landscape through isotope analyses on marine mollusc shell carbonates and human bone collagen. Quat. Int. 244, 88-104. https:// doi.org/10.1016/j.quaint.2011.05.044.

Marco-Barba, J., Holmes, J.A., Mesquita-Joanes, F., Miracle, M.R., 2013. The influence of climate and sea-level change on the Holocene evolution of a Mediterranean coastal lagoon: evidence from ostracod palaeoecology and geochemistry. Geobios 46 409-421. https://doi.org/10.1016/j.geobios.2013.05.003.

Marriner, N., Flaux, C., Morhange, C., Kaniewski, D., 2012. Nile Delta's sinking past: quantifiable links with Holocene compaction and climate-driven changes in sediment supply? Geology 40, 1083-1086. https://doi.org/10.1130/G33209.1.

Melis, R.T., Depalmas, A., Di Rita, F., Montis, F., Vacchi, M., 2017. Mid to late Holocene environmental changes along the coast of western Sardinia (Mediterranean Sea). Glob. Planet. Chang. 155, 29-41. https://doi.org/10.1016/j.gloplacha.2017.06.001.

Melis, R.T., Di Rita, F., French, C., Marriner, N., Montis, F., Serreli, G., Sulas, F., Vacchi, M., 2018. 8000 years of coastal changes on a western Mediterranean island: a multiproxy approach from the Posada plain of Sardinia. Mar. Geol. 403, 93-108. https:// doi.org/10.1016/j.margeo.2018.05.004.

Meyers, P.A., Teranes, J.L., 2001. Sediment organic matter. In: Last, W.M., Smol, J.P. (Eds.), Tracking Environmental Change Using Lake Sediments, Developments in Paleoenvironmental Research. Springer, Netherlands, pp. 239-269.

Morellón, M., Valero-Garcés, B., Moreno, A., González-Sampériz, P., Mata, P., Romero, O., Maestro, M., Navas, A., 2008. Holocene palaeohydrology and climate variability in northeastern Spain: the sedimentary record of Lake Estanya (Pre-Pyrenean range). In: Quaternary International, The Last 15ka of Environmental Change in Mediterranean Regions - Interpreting Different Archives. 181. pp. 15-31. https://doi.org/10.1016/j. quaint.2007.02.021.

Nesje, A., Dahl, S.O., Bakke, J., 2004. Were abrupt Lateglacial and early-Holocene climatic changes in northwest Europe linked to freshwater outbursts to the North Atlantic and Arctic Oceans? The Holocene 14, 299-310. https://doi.org/10.1191/ 0959683604hl708fa.

Pascucci, V., De, F., Del, V., Sanna, I., Melis, R.T., Andreucci, S., 2018. Climate changes and human impact on the Mistras coastal barrier system (W Sardinia, Italy). Mar. Geol. 395, 271-284. https://doi.org/10.1016/j.margeo.2017.11.002.

Redman, C.L., 2005. Resilience theory in archaeology. Am. Anthropol. 107, 70-77. https://doi.org/10.1525/aa.2005.107.1.070.
Reimer, P.J., McCormac, F.G., Moore, J., McCormick, F., Murray, E.V., 2002. Marine radiocarbon reservoir corrections for the mid to late Holocene in the eastern subpolar North Atlantic. The Holocene 12, 129-135. https://doi.org/10.1191/

$0959683602 \mathrm{hl} 528 \mathrm{rp}$.

Reimer, P.J., Bard, E., Bayliss, A., Beck, J.W., Blackwell, P.G., Ramsey, C.B., Buck, C.E., Cheng, H., Edwards, R.L., Friedrich, M., et al., 2013. IntCal13 and Marine13 radiocarbon age calibration curves 0-50,000 years cal BP. Radiocarbon 55, 1869-1887. https://doi.org/10.2458/azu js_rc.55.16947.

Rey, J., Fumanal, P.M., 1996. The Valencian coast (western mediterranean): neotectonics and geomorphology. Quat. Sci. Rev. 15, 789-802. https://doi.org/10.1016/S02773791(96)00069-8. L. Ortlieb.

Roy, K., Peltier, W.R., 2018. Relative sea level in the Western Mediterranean basin: a regional test of the ICE-7G NA (VM7) model and a constraint on late Holocene Antarctic deglaciation. Quat. Sci. Rev. 183, 76-87. https://doi.org/10.1016/j. quascirev.2017.12.021.

Shennan, I., Lambeck, K., Flather, R., Horton, B., McArthur, J., Innes, J., Lloyd, J., Rutherford, M., Wingfield, R., 2000. Modelling western North Sea palaeogeographies and tidal changes during the Holocene. Geol. Soc. Lond., Spec. Publ. 166, 299-319. https://doi.org/10.1144/GSL.SP.2000.166.01.15.

Siani, G., Paterne, M., Arnold, M., Bard, E., Métivier, B., Tisnerat, N., Bassinot, F., 2000 Radiocarbon reservoir ages in the Mediterranean Sea and Black Sea. Radiocarbon 42, 271-280. https://doi.org/10.1017/S0033822200059075.

Smith, D.E., Harrison, S., Firth, C.R., Jordan, J.T., 2011. The early Holocene sea level rise. Quat. Sci. Rev. 30, 1846-1860. https://doi.org/10.1016/j.quascirev.2011.04.019.

Somoza, L., Rey, J., 1991. El sector de plataforma en el tramo meridional del Golfo de Valencia. In: Presented at the VIII Reun. Nac. sobre Cuaternario, pp. 70-72.

Sturt, F., Garrow, D., Bradley, S., 2013. New models of North West European Holocene palaeogeography and inundation. J. Archaeol. Sci. 40, 3963-3976. https://doi.org/ 10.1016/j.jas.2013.05.023.

Thorndycraft, V.R., Benito, G., 2006. Late Holocene fluvial chronology of Spain: the role of climatic variability and human impact. In: CATENA, Past Hydrological Events Related to Understanding Global Change. 66. pp. 34-41. https://doi.org/10.1016/j. catena.2005.07.007.

Torres, T., Ortiz, J.E., Martín-Sánchez, D., Arribas, I., Moreno, L., Ballesteros, B., Blázquez, A., Domínguez, J.A., Estrella, T.R., 2014. The long Pleistocene record from the Pego-Oliva marshland (Alicante-Valencia, Spain). Geol. Soc. Lond., Spec. Publ. 388, 429-452. https://doi.org/10.1144/SP388.2.

Vacchi, M., Marriner, N., Morhange, C., Spada, G., Fontana, A., Rovere, A., 2016. Multiproxy assessment of Holocene relative sea-level changes in the western Mediterranean: sea-level variability and improvements in the definition of the isostatic signal. Earth Sci. Rev. 155, 172-197. https://doi.org/10.1016/j.earscirev. 2016.02.002.

Vacchi, M., Ghilardi, M., Spada, G., Currás, A., Robresco, S., 2017. New insights into the sea-level evolution in Corsica (NW Mediterranean) since the late Neolithic. J. Archaeol. Sci. Rep. 12, 782-793. https://doi.org/10.1016/j.jasrep.2016.07.006.

Van de Noort, R., 2011. Conceptualising climate change archaeology. Antiquity 85 1039-1048.

Viñals, M.P., Belluomini, G., Fumanal, M.P., Dupré, M., Usera, J., Mestres, J., 1993. Rasgos paleoambientales holocenos de la Bahía de Xábia (Alicante). In: Bernabeu, Fumanal (Eds.), Estudios sobre Cuaternario, Univ. Valencia-S.I.P, pp. 107-114.

Viñals, M.J., 1995. Secuencias estatigráficas y evolución morfológica del extremo meridional del Golfo de Valencia (Cullera-Dénia). El Cuaternario del País Valenciano 163-167.

Viñals, M.J., Fumanal, M.P., 1995. Quaternary development and evolution of the sedimentary environments in the Central Mediterranean Spanish coast. Quat. Int. 29-30, $119-128$

Viñals, M.J., Mateu, G., Fumanal, M.P., Usera, J., Favero, V., 1989. Aportación al conocimiento de las facies lagunares y litorales de la marjal de Oliva-Pego (Valencia). Cuaternario y Geomorfología 3, 93-104.

Walsh, K., 2014. The archaeology of Mediterranean landscapes. In: Human-Environment Interaction from the Neolithic to the Roman Period. Cambridge University Press (384 pp.).

Zazo, C., Dabrio, C.J., Goy, J.L., Lario, J., Cabero, A., Silva, P.G., Bardají, T., Mercier, N., Borja, F., Roquero, E., 2008. The coastal archives of the last $15 \mathrm{ka}$ in the Atlantic-Mediterranean Spanish linkage area: sea level and climate changes. Quat. Int. 181, 72-87.

Zilhão, J., 2001. Radiocarbon evidence for maritime pioneer colonization at the origins of farming in West Mediterranean Europe. PNAS 98, 14180-14185. https://doi.org/10. 1073/pnas. 241522898. 